\title{
PENGEMBANGAN RENCANA PELAKSANAAN PEMBELAJARAN (RPP LANJUTAN) PEMBELAJARAN BAHASA JEPANG BERBASIS STANDAR PROSES KURIKULUM 2013 REVISI UNTUK SEKOLAH DASAR DI BALI
}

\author{
P.K.R.Devi ${ }^{1}$, D.M.S. Mardani ${ }^{2}$, I.W. Sadyana ${ }^{3}$ \\ ${ }^{123}$ Jurusan Bahasa Asing, Universitas Pendidikan Ganesha, Singaraja \\ e- mail: krisda.ratma.devi@undiksha.ac.id, desak.mardani@undiksha.ac.id, \\ wayan.sadyana@undiksha.ac.id
}

\begin{abstract}
Abstrak
Penelitian ini bertujuan untuk menghasilkan RPP yang sesuai dengan standar proses kurikulum 2013 revisi untuk sekolah dasar (SD) di Bali. Jenis penelitian ini adalah penelitian pengembangan (research and development). Penelitian ini menggunakan model pengembangan Four-D oleh Thiagarajan yaitu define,design, develop dan disseminate.Namun pada tahap disseminate yang merupakan tahap penyebaran tidak di lakukan karena fokus penelitian ini sampai pada tahap develop atau pengembangan. Dalam penelitian ini subjeknya adalah guru pengajar bahasa Jepang Sekolah Dasar di Bali. Pengumpulan data dilakukan dengan memberikan kuesioner. Data yang telah diperoleh dianalisis dengan menggunakan teknik analisis deskriptif kualitatif. Hasil dari penelitian ini yaitu (1) berdasarkan hasil uji ahli materi menyatakan bahwa RPP yang telah dikembangkan ini sangat sesuai untuk digunakan, (2) Berdasarkan respons guru juga menyatakan RPP ini layak untuk digunakan dalam pembelajaran bahasa Jepang di Sekolah Dasar.
\end{abstract}

Kata kunci : Four-D Model, RPP, Kurikulum 2013 Revisi.

\section{要旨}

本研究の目的はバリ島の小学校に適した改訂された2013年カリキュラムプロセス基準に基づいて、学 習実施計画を作成することである。本研究は調査開発研（R\&D）であり、チアガラジャンの4D設計 モデル「定義、設計、開発、普及」を使用した。しかし、研究の焦点は開発にしか到達しなかったた め、普及段階は実行されませんでした。調査協力者はバリ島の小学校の日本語の教師である。調査方 法はアンケートである。このデータを定性的記述法により分析した。分析した結果、1）専門家のテ ストに基づいて、開発された学習実施計画は非常に適切で使用寸ることができる、2）回答者の教師 の結果に基づいて、小学校における日本語の学習ではこの学習実施計画は非常に適切で使用すること ができることである。

キーワード：4-D設計モデル、学習実施計画、改訂された2013年カリキュラム

\section{Pendahuluan}

Bahasa Jepang menjadi salah bahasa yang memiliki banyak peminat di Indonesia. Pernyataan ini dapat dibuktikan dengan adanya peninjauan oleh The Japan Foundation (2017) yang menunjukkan jumlah orang yang belajar bahasa Jepang di Indonesia menduduki peringkat ke-2 terbanyak yaitu dengan jumlah 745, 125 orang.

Bahasa Jepang dapat dipelajari secara formal atau non formal di Indonesia. Untuk pembelajaran bahasa Jepang secara formal dapat dipelajari di perguruan tinggi, sekolah menengah, bahkan untuk beberapa sekolah bahasa Jepang sudah diajarkan pada jenjang sekolah dasar (Danasasmita, 2017). Pembelajar bahasa Jepang di Indonesia tersebar pada jenjang yang berbeda, dimulai dari sekolah dasar (SD), sekolah menengah, perguruan tinggi, dan lain-lain. Dari 754, 125 orang pembelajar bahasa Jepang di Indonesia 6.504 orang pembelajar di antaranya merupakan siswa sekolah dasar (SD) (The Japan Foundation, 2017).

Pada jenjang sekolah dasar (SD), siswa yang belajar bahasa Jepang di Indonesia yang berjumlah 6.504 orang tersebar pada daerah-daerah yang ada di Indonesia, salah 
satunya adalah Bali. Siswa yang belajar bahasa Jepang di tingkat sekolah dasar (SD) di Bali tersebar pada 10 sekolah dasar (SD ) yaitu SD Saraswati 1 Denpasar, SD Saraswati 2 Denpasar, SD Saraswati 3 Denpasar, SD Saraswati 4 Denpasar, SD Saraswati 5 Denpasar, SD Saraswati 6 Denpasar, SD Saraswati Tabanan, SD Mutiara Singaraja, SD Tunas Kasih, SD Widiatmika. Pembelajaran bahasa Jepang pada 10 sekolah tersebut diberikan secara kurikuler maupun ekstra-kurikuler (Mardani dkk, 2020).

Melalui survey yang dilakukan oleh The Japan Foundation (2017) dapat diketahui bahwa bahan ajar untuk pembelajar bahasa Jepang di tingkat sekolah dasar (SD) masih dibuat sendiri oleh sekolah. Oleh karena itu pembelajaran bahasa Jepang di SD belum mendapat perhatian dari pihak terkait, termasuk The Japan Foundation yang merupakan lembaga yang bertugas dalam pembelajaran bahasa Jepang di luar Jepang. Hal ini disebabkan karena pembelajaran bahasa Jepang di Indonesia masih difokuskan pada jenjang SMA/SMK, sehingga menyebabkan pembelajaran bahasa Jepang di SD masih berpatokan pada kebijakan sekolah.

Pembelajaran yang diperuntukkan bagi anak-anak berbeda dengan orang dewasa. Menurut Yusuf (2013) anak-anak cenderung sulit memperhatikan sesuatu dalam waktu yang lama, kecuali untuk hal-hal yang dapat menarik perhatian mereka dan menyenangkan bagi mereka. Untuk hal-hal lain yang tidak menarik dan menyenangkan, mereka akan kesusahan untuk menaruh perhatian dalam kurun waktu yang lama. Hal ini sama dengan pembelajaran di sekolah dasar yang mengajarkan anak-anak, jika metode mengajar yang digunakan tidak tepat maka anak-anak akan sulit untuk memahaminya terlebih lagi saat ini kurikulum 2013 revisi menuntut siswa untuk lebih aktif dalam pembelajaran. Maka saat siswa tidak dapat memahami pelajaran, mereka juga akan sulit untuk aktif berperan dalam proses pembelajaran.

Saat ini di Indonesia telah menerapkan Kurikulum 2013 revisi. Kurikulum 2013 revisi adalah kurikulum yang diberlakukan secara nasional. Kurikulum ini menuntut agar siswa dapat berperan aktif dalam pembelajaran dan guru tidak lagi menjadi pusat dan orang yang serba tahu terhadap materi, tetapi siswa juga dapat memperoleh informasi dari berbagai sumber.

Penelitian terdahulu oleh Muryaningsih (2015), meneliti tentang pengembangan RPP. Penelitian ini memiliki tujuan untuk menghasilkan RPP tematik-integratif untuk meningkatkan karakter kerja keras pada anak dan juga mengetahui keefektifan hasil diterapkannya RPP tematik integratif ini dalam meningkatkan karakter kerja keras yang dimiliki oleh sisiwa. Model pengembangan yang dipakai adalah pengembangan menurut Brog \& Gall. Hasil penelitian ini menunjukkan produk berupa RPP yang dikembangkan layak digunakan. RPP yang dikembangkan efektif untuk dipergunakan dengan kriteria "sangat baik" dengan bukti keterlaksanaa $100 \%$.

Rencana pelaksanaan pembelajaran (RPP) adalah rencana yang digunakan untuk memberikan gambaran prosedur dan pengorganisasian pembelajaran agar dapat mencapai kompetensi yang diharapkan. Maka dari itu RPP yang dibuat untuk anak-anak sekolah dasar dapat menarik, menyenangkan dan juga membuat siswa paham. Di samping itu juga RPP diharapkan terdapat 4C (Communication, Collaboration, Critical Thinking and problem Solving, dan Creativity and Innovation), HOTS ( Higher Order Thinking Skill), literasi dan PPK di dalamnya (Inayah, 2013).

Sebelum dilakukannya penelitian ini sudah ada Buku ajar, silabus, dan RPP tahap awal jadi RPP yang dibuat pada penelitian ini adalah RPP tahap lanjutan. RPP tahap lanjutan ini di buat karena telah ada RPP tahap awal yang di buat oleh Ni Nengah Sukni yang juga berbasis standar proses kurikulum 2013 revisi untuk SD di Bali. RPP tahap awal adalah RPP yang ditujukan pada anak-anak sekolah dasar yang masih berada pada tahap pengenalan dalam belajar bahasa Jepang. Dilanjutkannya RPP tahap awal ini karena RPP tahap awal ditujukan pada anak-anak yang memulai belajar bahasa Jepang, sedangkan untuk anak-anak dengan jenjang lebih tinggi yang sudah cukup lama belajar bahasa Jepang juga memerlukan RPP yang sesuai dengan mereka. Maka dari itu dilanjutkanlah RPP tahap awal yang sudah ada menuju RPP tahap lanjutan. 
RPP tahap lanjutan merupakan RPP yang dibuat untuk siswa sekolah dasar (SD) pembelajar bahasa Jepang yang berada pada jenjang menengah ke atas. Materi yang terdapat pada RPP lanjutan memiliki tingkat kesulitan yang lebih tinggi di bandingkan tahap awal. Dalam RPP lanjutan yang sesuai dengan kurikulum 2013 revisi ini menggunakan pendekatan santifik, tetapi dalam pelaksanaannya dapat dilakukan secara acak sesuai dengan kebutuhan dan keadaan.

Untuk memenuhi tuntutan kurikulum dan mengatasi permasalahan terkait maka pengembangan rencana pelaksanaan pembelajaran (RPP lanjutan) pembelajaran bahasa Jepang berbasis standar proses kurikulum 2013 revisi untuk sekolah dasar di Bali sangat mendesak dan harus segera dilaksanakan.

\section{Metode}

Penelitian ini merupakan research and development (R\&D) yakni Pengembangan Rencana Pelaksanaan Pembelajaran (RPP Lanjutan) bahasa Jepang berdasarkan standar Proses Kurikulum 2013 Revisi yang memanfaatkan pendekatan kualitatif. Pendekatan kualitatif merupakan prosedur penelitian yang menghasilkan data deskriptif berupa kata-kata tertulis maupun lisan dari apa yang diamati. Penelitian ini merupakan penelitian tahap lanjutan yaitu penyusunan RPP bahasa Jepang berdasarkan Kurikulum 2013 Revisi untuk SD di Bali yang disesuaikan dengan kebutuhan guru dan Kurikulum 2013 Revisi.

Pada penelitian pengembangan ada banyak model penelitian yang dapat digunakan, tetapi dalam pemelitian ini menggunakan Four-D Model oleh Thiagarajan, S., dkk (1974) sebagai berikut.

Tahap pertama: Define merupakan tahap pertama, di mana pada tahap ini hal yang dilakukan adalah menentukan kebutuhan dilapangan, pada tahap ini terbagi menjadi lima yaitu.

a. Front-end analysis, pada tahap ini dilakukan analisis terkait permasalahan mendasar yang dihadapi oleh guru. Selama analisis dipertimbangkan beberapa alternatif yang mampu memecahkan masalah yang dihadapi oleh guru dalam pembelajaran. Dalam penelitian ini untuk menganalisis permasalahan yang dihadapi guru dalam mengajar bahasa Jepang, guru diminta untuk mengisi angket yang telah disipkan. Dalam angket tersebut terdapat hal-hal yang harus diisi oleh guru terkait dengan RPP yang digunakan dan terkait dengan penggunaan kurikulum 2013 revisi oleh sekolah.

b. Learner analysis, pada tahap ini dilakukan analisis untuk mengetahui bagaimana karakteristik siswa sekolah dasar tersebut. Karakteristik yang dimaksud adalah kompetensi dan pengalaman yang dimiliki siswa, bagaimna respon siswa terhadap materi pembelajaran, serta media yang digunakan saat pembelajaran, dan bahasa yang diminati. Penelitian ini bertujun untuk mengetahui karakteristik siswa, maka dilakukanlah wawancara secara terstruktur pada siswa terkait kesan mereka terhadap pembelajaran bahasa Jepang yang selama ini mereka dapatkan.

c. Task analysis, menganalisis keterampilan utama yang diperolah oleh siswa serta mengelompokkan keterampilan yang penting dan yang bisa diberikan secukupnya.

d. Concept analysis, mengidentifikasi konsep utama yang diajarkan, menyusun menjadi sebuah hierarki.

e. Specifying instructional objective, mengubah hasil dari task analisis dan consept analysis menjadi tujuan akhir. Tujuan tersebut menjadi dasar dari strukur dan desain pembelajaran. Yang nantinya akan terintegrasi dengan bahan pembelajaran.

Tahap kedua: Design ( membuat prototype/ draf perangkat pembelajaran), pada tahap ini hasil analisis pada tahap Define direalisasikan menjadi perangkat pembelajaran yang memang dibutuhkan oleh guru bahasa Jepang pada tingkat SD di Bali yang sesuai dengan kurikulum 2013 revisi.

Tahap ketiga: Develop (tahap uji ahli perangkat pembelajaran dan perbaikan berdasarkan masukan dari uji ahli). Pada tahap ini dilakukan pengujian validitas perangkat pembelajaran baik dari segi substansi isi materi atau pun secara empiris sebagai dasar untuk melakukan revisi. Uji ahli ini meliputi dua tahap, yaitu. 
a. Expert appraisal, dilakukan evaluasi oleh ahli. Feedback dari ahli digunakan untuk memperbaiki agar bahan pembelajaran lebih tepat, efektif, bermanfaat, serta berkualitas.

b. Developmental testing, meliputi uji coba terbatas yang dilakukan pada guru bahasa Jepang di SD Mutiara Singaraja, hal ini bertujuan untuk mengetahui kelayakan produk. Selain itu juga untuk mengetahui hal-hal yang harus diperbaiki agar produk yang dibuat semakin layak untuk digunakan. Perbaikan akan dilakukan berdasarkan reaksi dan pendapat guru pengajar bahasa Jepang di SD Mutiara Singaraja.

Tahap keempat: Disseminate (penyebran)

Pada tahap ini dilakukan pengemasan final, penyebaran serta pemakaian. Pada penelitian ini, tahap keempat ini tidak dilakukan karena penelitian ini hanya difokuskan pada tahap develop atau pengembangan, .

Sebelum sebuah produk dimyatakan layak digunakan atau tidak harus dilakukan uji ahli pada beberapa ahli untuk memberikan penilaian dan masukan terkait produk yang dibuat. Setelah uji ahli selesai dilakukan dan perbaikan sesuai dengan saran ahli telah selesai dilakukan, maka dilanjutkan dengan uji coba produk. Uji coba pada penelitian ini dilakukan secara terbatas. Uji coba ini dilakukan bertujuan untuk melihat respons dari guru pengajar terkait produk yang telah dibuat.

Dalam penelitian ini subjek penelitiannya adalah guru pengajar bahasa Jepang pada sekolah dasar yang di Bali, di antaranya SD saraswati 1 Denpasar, SD Saraswati 2 Denpasar, SD Saraswati 3 Denpasar, SD Saraswati 4 Denpasar, SD Saraswati 5 Denpasar, SD Saraswati 6 Denpasar, SD Saraswati Tabanan, SD Mutiara Singaraja, SD Tunas Kasih, SD Widiatmika. Saat uji coba, hanya dilakukan secar terbatas pada guru pengajar bahasa Jepang di SD Mutiara Singaraja.

Penelitian ini menggunakan metode pengumpulan data berupa wawancara dan angket/kuesioner. Berikut pemaparannya.

1. Wawancara

Wawancara menurut Blaxter dkk. (dalam Nugraha, 2015) melibatkan pengajuan pertanyaan atau pembahasan mengenai hal-hal tertentu dengan orang yang bersangkutan dengan penelitian.

Dalam penelitian ini wawancara dilakukan secara random terhadap 3-5 orang siswa di setiap sekolah dasar yang memberikan pelajaran bahasa Jepang. Dengan rincian sebagai berikut.

SD saraswati 1 Denpasar $=5$ orang, SD Saraswati 2 Denpasar $=4$ orang, SD Saraswati 3 Denpasar $=5$ orang, SD Saraswati 4 Denpasar $=5$ orang, SD Saraswati 5 Denpasar $=4$ orang, SD Saraswati 6 Denpasar $=4$ orang, SD Saraswati Tabanan $=5$ orang, SD Mutiara Singaraja $=5$ orang, SD Tunas Kasih $=5$ orang, SD Widiatmika $=3$ orang. Sehingga total jumlah siswa yang diwawancarai adalah 43 orang.

2. Angket/ kuesioner

Angket/ kuesioner menurut Mardalis (dalam Sunarna, 2010) adalah teknik pengumpulan data dengan memberikan formulir yang berisi pertanyaan- pertanyaan yang diajukan secara tertulis pada seseorang atau sekumpulan orang untuk memperoleh informasi yang diperlukan.

Dalam penelitian ini pengisian angket dilakukan oleh pengajar bahasa Jepang yang ada pada setiap sekolah dasar dan validator saat uji ahli. Angket yang digunakan adalah angket kombinasi antara angket terbuka dan tertutup. Angket kombinasi adalah angket yang di dalamnya terdapat pilihan jawaban, tetapi responden diberikan kebebasan untuk memberikan pendapat selain mengisi pilihan pada angket.

Instrumen Pengumpulan Data

Instrumen pengumpulan data yang digunakan pada penelitian ini, sebagai berikut.

1. Pedoman Wawancara

Pengumpulan data dengan wawancara dilakukan dengan memberikan pertayaan pada siswa sekolah dasar yang mendapatkan pelajaran bahasa Jepang di Bali secara terstruktur. Dalam wawancara, dibuatlah pedoman wawancara berupa pertanyaan-pertanyaan yang ingin ditanyakan. Wawancara ini dilakukan secara 
terstruktur agar dapat lebih mudah mengingat pertanyaan yang akan diberikan pada siswa sekolah dasar dan juga agar informasi yang dicari dapat tersusun dengan baik. Selain itu juga dengan digunakannya wawancara terstruktur maka pertanyaan yang terlewatkan lebih sedikit, sehingga informasi yang diperoleh bisa lebih lengkap.

2. Lembar Angket

Lembar angket yang dibuat akan diberikan kepada guru dan validator saat uji ahli untuk diisi. Lembar angket yang diberikan berisi 18 buah pertanyaan. Dalam angket ini komponen yang dinilai adalah a. kesesuaian RPP dengan kurikulum 2013 revisi, b. timbulnya keterampilan abad 21 (4C), HOTS, PPK, dan literasi, c. Kejelasan kompetensi dasar, d. Kesesuaian indikator dan kompetensi dasar, e. Kesesuaian tujuan dengan kompetensi dasar, f. Kesesuaian materi pembelajaran dengan kompetensi dasar, g. kesesuaian indikator pencapaian dengan materi pembelajarann, h.kesesuaian materi dengan tujuan pembelajaran, i. Pemanfaatan teknologi sebagai media pembelajaran, j. Kesesuaian model pembelajaran dengan tujuan, k. Pemilihan model pembelajaran sesuai dengan tuntutan kurikulum, I. Kejelasan langkah-langkah pembelajaran, m. Kesesuaian langkah-langkah pembelajaran dengan keterampilan abad 21 (4C), literasi, HOTS, PPK, n. Ketepatan penilaian terhadap tujuan pembelajaran/ kompetensi dasar, o. Kesesuaian penilain dengan kurikulum 2013 revisi, p. Penggunaan bahasa dalam RPP, q. Kelengkapan instrumen penilaian.

Pengisian angket uji ahli dilakukan pada 15 Oktober 2019 untuk penguji 1, dan tanggal 22 Januari 2020 untuk penguji 2. Sedangkan angket yang diisi oleh guru yaitu saat uji coba terbatas yang dilakukan di SD Mutiara Singaraja pada 24 januari 2020. Guru dan penguji akan diminta untuk memberikan centang sesuai dengan indikator peniilaian angket yaitu Sangat Sesuai (SS), Sesuai (S), Cukup Sesuai (CS), Kurang Sesuai (KS), Sangat Tidak Sesuai (STS). Selan itu Validator dan guru berhak untuk memberikan masukan, penilaian, saran, komentar dan pendapat mereka mengenai RPP yang telah dikembangkan.

Tabel 3.1

Kriteria Tingkat Validitas RPP

$76<\mathrm{SR} \leq 100$

Kriteria Tingkat Validitas Perangkat Pembelajaran SKOR

$51<\mathrm{SR} \leq 75$

$26<\mathrm{SR} \leq 50$

$0<\mathrm{SR} \leq 25$

SKOR

Sangat Sesuai (SS)

Sesuai (S)

Kurang Sesuai (KS)

Tidak Sesuai (TS)

Keterangan :

Kirna (dalam Juliantini, 2019)

$S R=\frac{\text { Jumlah skor dari semua item }}{\text { Jumlah skor maksimal }} X 100$

$\mathrm{SR}=$ Skor rata-rata berdasarkan hasl validasi

Dalam penelitian ini, skor rata-rata minimal yang dicapai yaitu dari interval $51<\mathrm{SR} \leq 75$.

Dengan demikian RPP yang dikembangkan dinyatakan layak digunakan.

\section{Hasil dan Pembahasan}

Penelitian ini menghasilkan perangkat pembelajaran. Dalam penelitian ini perangkat pembelajaran yang dikembangkan adalah Rencana Pelaksanaan pembelajaran (RPP) yang ditujukan untuk sekolah dasar di Bali yang mendapatkan pembelajaran bahasa Jepang.

Di Bali terdapat 10 sekolah dasar yang memberikan pelajaran bahasa Jepang yaitu yaitu SD Saraswati 1 Denpasar, SD Saraswati 2 Denpasar, SD Saraswati 3 Denpasar, SD Saraswati 4 Denpasar, SD Saraswati 5 Denpasar, SD Saraswati 6 Denpasar, SD Saraswati Tabanan, SD Mutiara Singaraja, SD Tunas Kasih, dan SD Widiatmika.

RPP yang dibuat pada penelitian ini adalah RPP tahap lanjutan. Tahap lanjutan berarti tahapan menengah ke atas yang merupakan tahap yang lebih tinggi dari tahap awal. RPP 
tahap lanjutan ini terdiri dari 15 bab. RPP ini terdiri dari beberapa komponen di antaranya, identitas sekolah (nama sekolah, mata pelajaran, kelas/semester, materi pokok, alokasi waktu), kompetensi inti, kompetensi dasar dan indikator pencapaian kompetensi, tujuan pembelajaran, meteri pembelajaran, metode pembelajaran, media pembelajaran, sumber belajar, langkah-langkah pembelajaran, dan penilaian.

RPP ini disesuaikan dengan kurikulum 2013 revisi. Dalam RPP terdapat PPK (Penguatan Pendidikan Karakter ) yaitu religius, nasionalis, kemandirian, gotong royong, dan integritas. Selain itu juga terdapat $4 \mathrm{C}$ yang terdiri dari Communication, Collaboration, Critical Thinking and problem Solving, dan Creativity and Innovation yang merupakan keterampilan abad 21 yang terdapat pada kurikulum 2013. Pada kegiatan pembelajaran juga terdapat literasi yang menuntut siswa untuk untuk mengolah dan memahami informasi saat melakukan aktivitas membaca, menulis, mendengarkan, dan berbicara. Dalam pembelajaran juga siswa dituntut untuk memiliki cara berpikir tingkat tinggi (Higher Order Thingking Skill), sehingga menuntut siswa untuk berpikir kritis, logis, reflektif, dan berpikir kreatif.

Materi yang dimuat dalam RPP ini tediri dari 15 bab meliputi, ruangan di rumah, nama benda di dalam rumah, binatang kesukaan, buah-buahan kesukaan, makanan dan minuman kesukaan, pekerjaan/ profesi orang tua, nama-nama negara, letak suatu benda, hobi sendiri dan teman, kepemilikan benda, kondisi benda, kegiatan sehari-hari, jadwal kegiatan di rumah, kegiatan yang berurutan, mengajak teman beraktivitas. Dalam RPP ini juga terdapat permainan-permainan ringan pada setiap babnya, yang membuat siswa SD lebih berminat dan lebih mudah dalam belajar bahasa Jepang.

Langkah-langkah pembelajaran dalam RPP ini dibuat dengan terstruktur dimulai dari pembuka/ pengenalan dalam pembelajaran (donyuu), kemudian tahap latihan dasar (kihon renshuu), dan yang terakhir adalah menggunakan atau mengaplikasikan hal yang telah dipelajari (ouyou renshuu). Hal ini sesuai dengan pembelajaran bahasa Jepang dasar. Selain itu juga dalam setiap bab pada langkah-langkah pembelajaran terdapat game/ permainan yang akan mempermudah anak-anak sekolah dasar dalam dalam memahami pelajaran dan juga dapat menarik minat mereka untuk belajar. Hal ini sesuai dengan pendapat Khairi (2018) yang menyatakan bahwa anak memiliki cara belajar yang berbeda dengan orang dewasa, sehingga dalam pembelajaran harus disesuaikan dengan karakteristik anak, salah satu karakteristik anak adalah anak belajar melalui bermain, sehingga pembelajaran yang didapatkan dapat dipahami.

Penelitian ini menggunakan model penelitian Four-D dari Thiagarajan, S., dkk (dalam Mardani dkk, 2019). Langkah-langkah model penelitian Four-D adalah Define, Design, Develop, dan Disseminate yang artinya tahap menentukan kebutuhan, perancangan, pengembangan dan penyebaran. Pada tahap Disseminate tidak dilakukan karena keterbatasan waktu penelitian. Berikut adalah pemaparan model penelitian Four- $D$ dalam penelitian ini.

Tahap pertama, hal pertama yang dilakukan adalah analisis kebutuhan. Analisis kebutuhan dilakukan dengan dengan meminta guru bahasa Jepang sekolah dasar mengisi angket dan mewawancarai siswa SD secara random 3-5 orang, hasilnya adalah guru masih menjadi pusat dan sumber utama dalam belajar sehingga pembelajaran bahasa Jepang di sekolah dasar belum sesuai dengan kurikulum 2013 revisi. Untuk mengubah cara belajar dalam proses pembelajaran, hal yang di perlukan adalah RPP (rencana pelaksanaan pembelajaran) yang merupakan rancangan yang di buat oleh guru sebelum melaksanakan pembelajaran untuk mencapai satu atau lebih kompetensi dasar yang telah ditetapkan, hal ini sesuai dengan pengertian RPP menurut Permendikbud Nomor 22 Tahun 2016.

Tahap kedua, Setelah melakukan analisis kebutuhan, selanjutnya adalah merencanakan RPP yang akan dibuat. Pada tahap ini ada beberapa hal yang harus direncanakan yaitu terkait dengan susunan RPP yang dibuat seperti identitas sekolah diantaranya nama sekolah, mata pelajaran, kelas/semester, materi pokok, dan alokasi waktu. Pada bagian kelas/ semester pada RPP ini tidak tercantum kelas berapa yang akan menggunakan RPP ini, karena setelah melakukan studi pendahuluan pada sekolah dasar yang mendapat bahasa Jepang di Bali, setiap sekolah mulai belajar bahasa Jepang pada 
jenjang yang berbeda. Sehingga guru yang akan menyesuaikan atau mengisi bagian kelas/ semester sesuai dengan keadaannya.

Menentukan kompetensi inti. Kompetensi inti dalam RPP terdiri dari empat kompetensi diantaranya (1) sikap spiritual, (2) sikap sosial, (3) pengetahuan, (4) keterampilan. Kompetensi inti pada RPP menyesuaikan pada kompetensi inti yang ada pada silabus tahap lanjut. Pada bagian sikap spiritual yang berkaitan dengan menghargai agama yang diantutnya dan juga sikap sosial yang berkaitan dengan menentukan perilaku yang jujur, disiplin, santun dll. Dalam kurikulum 2013 revisi pada bagian sikap spiritual dan sikap sosial tidak lagi dinilai secara langsung, kecuali pada pelajaran PPKN dan agama. Selanjutnya pada bagian pengetahuan yang berhubungan dengan memahami pengetahuan faktual, konseptual, prosedural, dan metakognitif pada tingkat dasar dengan cara: a) mengamati, b) menanya, c) mencoba berdasarkan rasa ingin tahu tentang dirinya, makhluk ciptaan Tuhan dan kegiatannya, dan benda-benda yang dijumpainya di rumah, di sekolah, dan tempat bermain. Sedangkan keterampilan yang berkaitan dengan menunjukan keterampilan berpikir dan bertindak: a) kreatif, b) produktif, c) kritis, d) mandiri, e) kolaboratif, dan f) komunikatif dalam bahasa yang jelas, sistematis, logis dan kritis, dalam karya yang estetis, dalam gerakan yang mencerminkan prilaku anak sesuai dengan tahap perkembangannya.

Pada bagian pengetahuan dan keterampilan mencakup keterampilan abad 21 , HOTS, 4C, literasi, PPK yang akan diterapkan pada kegiatan pembelajran, keempat hal tersebut merupakan komponen yang harus ada dalam RPP yang sesuai dengan Kurikulum 2013 Revisi.

Menentukan kompetensi dasar dan indikator pencapaian kompetensi. Kompetensi dasar dan indikator pencapaian kompetensi dalam RPP dikutip dari silabus. Dalam RPP ini terdapat tiga kompetensi dasar yang disesuaikan dengan karakteristik peserta didik yang akan dicapai melalui indikator pencapaian kompetensi dan kegiatan pembelajaran. RPP yang dikembangkan merupakan RPP yang sesuai dengan kurikulum 2013 revisi, yang di dalamnya terdapat 4C, HOTS, Literasi dan PPK.

Dalam RPP ini 4C dan HOTS terdapat dalam kompetensi inti dan kompetensi dasar yang nantinya menjadi acuan untuk menentukan indikator pencapaian kompetensi dan tujuan pembelajaran. Dalam pengaplikasian dilapangan guru dapat menggunakan metode pembelajaran yang beragam tetapi tujuan pembelajaran harus disesuaikan dengan kompetensi dasar dan indikator yang ada.

Materi yang terdapat dalam RPP ini juga disesuaikan dengan kebutuhan peserta didik dan perkembangan kemampuannya. Materi yang ada pada 15 bab RPP memberikan gambaran yang dapat dilakukan oleh peserta didik dalam kegiatan pembelajaran. Materi RPP pada tahap lanjutan ini adalah untuk bab 16 : ruangan di rumah, bab 17: nama benda di dalam rumah, bab 18: binatang kesukaan, 19: buah-buahan kesukaan, bab 20: makanan dan minuman kesukaan, bab 21: pekerjaan/ profesi orang tua, bab 22: nama-nama Negara, bab 23: letak suatu benda, bab 24: hobi sendiri dan teman, bab 25: kepemilikan benda, bab 26: kondisi benda, bab 27: kegiatan sehari-hari, bab 28: jadwal kegiatan di rumah, 29: kegiatan yang berurutan, 30: mengajak teman beraktivitas. Dalam materi tahap lanjutan ini hal yang dibahas adalah penggunaan kosa kata, pengenalan ungkapan sederhana dan pengenalan ungkapan bentuk perintah yang ada pada setiap bab.

Metode pembelajaran yang digunakan pada RPP ini terbagi menjadi tiga yaitu pendekatan, model pembelajaran dan metode pembelajaran. Pendekatan yang digunakan dalam RPP ini adalah pendekatan saintifik (5M) yang terdiri dari mengamati, menanya, mengeksplorasi, mengasosiasi, dan mengomunikasikan. Pengaplikasikan 5M dalam RPP kurikulum 2013 revisi tidak harus dilakukan berurutan tetapi bisa diaplikasikan secara acak sesuai dengan kebutuhan. Selanjutnya model pembelajaran yang digunakan dalam RPP ini adalah Discovery Learning dan Problem Based Learning. Dengan diterapkannya Discovery Learning bertujuan agar peserta didik dapat berusaha untuk menemukan sendiri hal yang harus mereka pelajari dengan beberapa petunjuk dari guru. Sedangkan Problem Based Learning diterapkan memiliki tujuan untuk membiasakan peserta didik untuk belajar melalui masalah, sehingga peserta didik berusaha untuk menemukan pemecahan masalah tersebut. 
Dengan diterapkannya kedua model pembelajaran ini akan membuat peserta didik lebih aktif dalam pembelajaran dan membiasakan peserta didik untuk menemukan sendiri dan mempelajari sesuatu melalui masalah hal ini sesuai dengan pendapat Khairi (2018) bahwa anak belajar paling baik jika mempertimbangkan keseluruhan aspek pengembangan dan bermakna.

Metode pembelajaran yang digunakan adalah Ceramah, permainan, dan diskusi. Hal ini karena saat diterapkannya discovery learning atau siswa diminta untuk menemukan sendiri, misalnya mereka harus menemukan ungkapan dalan sebuah percakapan, maka setelah siswa berhasil menemukan ungkapan guru akan menggunakan metode ceramah untuk mengonfirmasi benar atau tidaknya ungkapan yang ditemukan oleh siswa. Selanjutnya metode permainan. Dalam RPP yang dikembangkan ini terdapat permainan pada setiap babnya. Adanya permainan ini bertujuan agar siswa dapat belajar lebih mudah dan dapat bermain dalam waktu yang bersamaan. Sehingga siswa tidak akan tertekan dalam proses pembelajaran hal ini sesuai dengan pendapat Khairi (2018) bahwa anak-anak belajar melalui bermain untuk mendapatkan hasil yang maksimal. Kemudian metode diskusi yang diterapkan dengan tujuan siswa dapat menerapkan 4C yaitu siswa dapat berkomunikasi dalam diskusi, berkolaborasi untuk memecahkan masalah, berpikir kritis, memecahkan masalah dengan pemikiran yang kreatif.

Media pembelajaran yang digunakan dalam RPP ini adalah Video/ power point, dan gambar. Dengan diberikannya metode visual pada siswa bertujuan agar siswa dapat belajar lebih mudah dengan visual yang dapat dilihat langsung. Sedangkan alat/ bahan yang digunakan LCD, proyektor, dan papan tulis yang bertujuan untuk memudahkan dalam memvisualisasikan video, power point ataupun gambar. Semua ini pada intinya bertujuan untuk mempermudah siswa dalam belajar sehingga dapat mencapai tujuan pembelajaran yang telah ditentukan.

Sumber belajar yang digunakan dalam RPP ini adalah buku ajar yang dibuat oleh dosen yang berjudul "Uki Uki Manabo".

Selanjutnya adalah langkah-langkah pembelajaran dalam RPP. Langkah-langkah pembelajaran dalam RPP ini dimulai dari pendahuluan yang berisi salam pembuka, memeriksa kehadiran siswa, mengaitkan materi hari ini dengan materi sebelumnya atau mengaitkan materi dengan kehidupan sehari-hari, guru memberi gambaran manfaat mempelajari materi tersebut dalam kehidupan sehari-hari, dan menyampaikan tujuan pembelajaran. Setelah pendahuluan akan dilanjutkan dengan kegiatan inti dalam pembelajaran. Dalam kegiatan inti guru akan mulai menerapkan $5 \mathrm{M}$ seperti mengamati dengan mulai menayangkan media visual berupa video dan meminta siswa untuk menemukan kosa kata yang ada dalam video. Kemudian menanya, guru akan menanyakan kosa kata apa saja yang telah ditemukan oleh siswa, selanjutnya guru aka mengonfirmasi kebenaran dari kosa kata yang ditemukan oleh siswa. Selanjutnya akan ada permainan/game yang akan melibatkan siswa, sehingga membuat siswa lebih tertarik dalam belajar. Game dalam RPP ini lebih banyak memanfaatkan gambar/ visual agar dapat membuat siswa melihat hal yang konkret untuk mempermudah mereka dalam belajar. Selanjutnya akan ada diskusi kelompok. Dalam diskusi kelompok siswa akan diminta membentuk kelompok, kemudian akan diberikan wacana atau percakapan singkat yang memiliki bagian rumpang. Selanjutnya siswa akan diminta utuk menemukan inti dari wacana atau percakapan dan juga melengkapi bagian rumpang pada wacana atau percakapan tersebut. Setelah selesai berdiskusi setiap kelompok akan diminta untuk mempresentasikan hasil diskusi mereka kemudian kelompok lain menanggapi presentasi temannya. Setelah semua kelompok mempresentasikan hasil diskusinya maka guru akan mengonfirmasi kebenaran dari jawaban mereka. Setelah itu guru menjelaskan sedikit tentang ungkapan yang ditemukan siswa dan memberikan contoh lain. Selanjutnya siswa akan diminta untuk membuat ungkapan. Setelah siswa selesai membuat ungkapan guru akan meminta beberapa siswa untuk membacakan ungkapan mereka. Yang terakhir adalah penutup. Guru akan meminta siswa untuk menyimpulkan pembelajaran dan meminta siswa mempelajari materi selanjutnya. Setelah itu guru akan menutup pembelajaran dengan salam penutup. 
Dalam RPP yang dikembangkan ini alokasi waktu atau pertemuan dalam setiap bab itu berbeda-beda, ada yang menggunakan 2 kali pertemuan dengan masing-masing waktu 2 jam pelajaran, 1 kali pertemuan dengan 2 jam pelajaran atau 3 kali pertemuan dengan masing-masing 2 jam pembelajaran. Hal ini ditentukan dalam silbus tahap lanjutan dan telah disesuaikan dengan RPP tahap lanjutan.

Selanjutnya adalah pemilaian. Penilaian dalam RPP ini terdiri dari penilaian sikap dengan observasi/pengamatan/jurnal, penilaian pengetahuan dengan tes pemahaman dan penilaian keterampilan dengan unjuk kerja/ praktik

Tahap ketiga Setelah produk dikembangkan dan telah selesai dibuat, selanjutnya dilakukan uji ahli. Uji ahli bertujuan untuk meminta bantuan penguji untuk memberi masukan, kritik dan saran untuk menyempurnakan produk. Uji ahli yang dilakukan adalah uji ahli materi oleh 2 orang dosen Universitas Pendidikan Ganesha. Uji ahli dilakukan dengan memberikan angket pada penguji. Angket berisi hal-hal terkait dengan RPP yang telah dikembangkan dan juga kolom masukan atau saran yang bisa diisi oleh penguji untuk menyempurnakan produk. Hasil penilaian uji ahli materi 1 menunjukkan 95,5 yang berarti sangat sesuai. Hasil penilaian uji ahli materi 2 menunjukkan 91,1 yang berarti sangat sesuai. Setelah uji ahli maka akan dilakuan perbaikan sesuai dengan saran, masukan atau kritik yang diberikan oleh penguji untuk menyempurnakan produk.

Setelah produk diperbaiki maka dilakukan uji coba/ uji kelayakan pada sekolah dasar yang mendapatkan pembelajaran bahasa Jepang di Bali. Namun karena keterbatasan waktu dan jarak yang jauh, maka uji coba hanya dilakukan di SD Mutiara, Singaraja. Uji coba dilakukan oleh guru pembina ekstrakulikuler SD Mutiara, Singaraja. Uji coba dilakukan dengan memberikan angket pada guru yang berhubungan dengan RPP yang telah dikembangkan. Hasil uji coba menunjukkan 88,8 yang berarti sangat sesuai.

Berdasarkan uji ahli materi yang dilakukan oleh 2 orang penguji yang merupakan dosen di Universitas Pendidikan Ganesha dan uji coba/ kelayan produk pada guru Pembina ekstrakulikuler SD Mutiara, Singaraja menunjukkan bahwa RPP yang dibuat sangat sesuai untuk diterapkan pada sekolah dasar yang mendapatkan pembelajaran bahasa Jepang di Bali.

Ada pun kelebihan RPP bahasa Jepang untuk sekolah dasar di Bali yang di kembangkan sebagai berikut.

1. RPP yang dikembangkan telah sesuai dengan kurikulum 2013 revisi. Dalam RPP yang dikembangkan ini dalam penyusunannya memuat terdapat 4C (Communication, Collaboration, Critical Thinking and problem Solving, dan Creativity and Innovation), HOTS ( Higher Order Thinking Skill), literasi dan PPK.

2. RPP yang dikembangkan memuat permainan/game ringan tiap babnya yang membuat siswa SD berminat dan lebih mudah untuk belajar.

\section{Simpulan dan Saran}

Simpulan dari rencana pelaksanaan pembelajaran (RPP) berbasis standar proses kurikulum 2013 revisi untuk sekolah dasar di Bali adalah sebagai berikut.

Rencana pelaksanaan pembelajaran (RPP) dikembangkan dengan menggunakan Four-D Model milik Thiagarajan yang memiliki empat tahapan yang terdiri dari Define, Design, Develop, dan Disseminate yang artinya tahap menentukan kebutuhan, perancangan, pengembangan dan penyebaran. RPP yang dikembangkan terdiri tari 15 bab yang disesuaikan dengan kebutuhan sekolah dasar di Bali secara holistik. Setiap bab disusun dengan urutan, nama sekolah, mata pelajaran, kelas/semester, materi pokok, alokasi waktu, kompetensi inti, kompetensi dasar dan indikator pencapaian kompetensi, tujuan pembelajaran, meteri pembelajaran, metode pembelajaran, media pembelajaran, sumber belajar, langkah-langkah pembelajaran, dan penilaian. Setiap bab pada RPP juga terdapat permainan yang dapat membuat siswa lebih tertarik dalam belajar dan mudah dalam memahami pembelajaran.

Berdasarkan rangkuman dan kesimpulan di atas, dapat disarankan beberapa hal sebagai berikut.

1. Bagi Guru Bahasa Jepang 
Disarankan bagi guru-guru untuk memberikan atau menyisipkan permainan-permainan ringan dalam pembelajaran agar pembelajaran bahasa Jepang dapat lebih menyenangkan dan mudah diterima oleh siswa.

2. Bagi Penelitian Lain

Bagi peneliti lain/ mahasiswa lain yang meneliti mengenai RPP bahasa Jepang untuk sekolah dasar, disarankan agar dalam RPP yang dikembangkan memuat permainan yang lebih bervariasi lagi untuk membuat siswa semakin tertarik untuk belajar bahasa Jepang.

\section{Daftar Pustaka}

Danasasmita, Wawan. 2017. "Guru Bahasa Jepang di Indonesia: Peluang dan Tantangan". Tersedia pada http:// www.academia.edu/6127417/Guru Bahasa Jepangdi Indonesia pekuang dan Tantangan.html diakses pada tanggal 11 Juni 2019.

Juliantini, Ni Komang. 2019. Pengembangan Buku Ajar Bahasa Jepang Dalam Kegiatan Ekstrakulikuler Bahasa Jepang Di SD Mutiara Singaraja. Skripsi. Jurusan Pendidikan Bahasa Jepang Fakultas Bahasa Dan Seni, Universitas Pendidikan Ganesha Singaraja.

Mardani, D.M.S., Sadyana, I.W., \& Adnyani, L.D.S. 2020. Learning Japanese Language Based on 2013 Curriculum at Elementary School in Bali. Proceeding of $3^{\text {rd }}$ International Conference on Innovative Research Across Disciplines (ICIRAD 2019), 246-251. https://dx.doi.org/10.2991/assehr.k.200115.040

Muryaningsih, Sri. "Pengembangan RPP Tematik-Integratif untuk Meningkatkan Karaker Kerja Keras di Kelas 1 SD N 2 Sokaraja Tengah."Jurnal Prima Edukasia. Volume 3 Nomor 2.

Nugraha, M Sofwan. 2015. "Pembelajaran PAI Berbasis Media Digital". Tersedia pada repository.upi.edu. Diakses pada 11 Juni 2019.

Sunarna, Ignasius Tri. 2010. "Metode Penelitian". Tersedia pada repository.upi.edu. Diakses pad 11 Juni 2019.

The Japan Foundation. 2017. Survey Report on Japanese-Languagae Education Aboard 2015. Tokyo. Diakses pada https:// www.jpf.go.jp/e/project/japanese/survey/result/survey15.html pada tanggal 10 Juni 2019.

Thiagarajan, S., Semmel, D, Semel, M. 1974. Instructional Development for Traning Teacher of Exceptional Children. Indian: ERIC.

Yusuf, Syamsu. 2013. Perkembangan Peserta Didik. Cetak Ke-4. Jakarta: PT Rajagrafindo Persada. 